\title{
SOME STUDIES ON THE OCCURRENCE OF PSEUDOMONAS AERUGINOSA ISOLATED FROM FARM ANIMALS
}

\author{
Ola. A. M. Basha \\ Department of Bacteriology, Animal Health Research Institute, Alexandria Branch
}

\section{ABSTRACT}

A total number of 50 samples were collected from clinically diseased farm animals including diarrhoea in calves, mastitis in cows, respiratory affections in sheep and abscess formation in sheep and goats at different localities in Alexandria Governorate to detect the prevelance of Pseudomonas species. Pseudomonas aeruginosa was isolated from these samples at a rate of $20 \%$, where the isolation from 10 samples of diarrhoeic calves, 12 mastitic milk of cows, 10 nasal swabs of sheep, 10 samples of pneumonic lung of sheep and 8 wounds and abscess swabs of sheep and goats were at: 10, 8.3, 20, 40, $25 \%$ respectively. Moreover, 8 strains out of these positive strains gave positive hemolysin activity (B- Hemolysis) onto blood agar plates while experimental infection with isolated Pseudomonas aeruginosa revealed death of all embryos inoculated via yolk sac route. In- vitro antimicrobial sensitivity results revealed that the isolated Pseudomonas aeruginosa were sensitive to Ofloxacine, Ciprofloxacin, Gentamycin but resistant to Nitrofuratoin, Amoxicillin, Cefotaxime, Amoxicillin calvulanic acid, Erythromycin, Trimethoprim. The antimicrobial activities of four different plant extracts (Ginger, Thyme, black seed, Cinnamon) which had antibacterial effects to some species of microorganisms were studied to the multi-drug resistant isolates of Pseudomonas aeruginosa in this research but they recorded no inhibition zones. 


\section{INTRODUCTION}

Pseudomonas species has been described as an environmental bacterium which can survive in polymicrobial societies, they widely distributed in nature as they are natural residents of soil and water, majority of the members of the group are motile, all are gram negative pathogen.

The most pathogenic species is Pseudomonas aeruginosa which represent a reason of infection in man, animals, poultry and fish; the others are saprophytic and occur widely in nature.

Pseudomonas aeruginosa is a gram negative rod shaped bacterium which is implicated in its pathogenicity as it produces an enterotoxin that is responsible for gastroenteric disorder such as diarrhea and enteritis in calves (Quinn et al., 2002). In addition, it produces several protein exotoxins and various extra cellular products that could play an important role in its pathogenicity (Jaime H.Samour, 2000).

Pseudomonas aeruginosa is an opportunistic pathogen may cause infection in respiratory tract mainly in its lower part, wounds, and urinary tract (Rahul Mittal 2006). Pseudomonas aeruginosa is responsible for cases of reproductive disorders in cows such as intrauterine infection (Kolev et al.,1983) as well as Mastitis (Howell 1972).

Moreover, Pseudomonas aeruginosa could be isolated from cases of otitis externa in Awassi sheep (Al-Farwachi and Al . Hassan, 2008), also it perform a reseon of suppurative arthritis in sheep (Arslan, et al., 2009). 
In addition, Pseudomonas aeruginosa is a pathogen highly resistant to chemical and pharmaceutical products due to its genetic factor (Cornialis, 2008 ; Todar's 2008) So the treatment represent a problem due to its resistance to wide range of antibiotics (Kovac's et al., 1998). Some scientists try to found a natural and efficient substances which has the ability to inhibit growth of bacteria which can resist antibiotics (Arici, et al., 2005).

The aim of this study is to throw light on occurrence of Pseudomonas aeruginosa in farm animals, investigate the virulence and pathogenicity of the isolates, and studying its response to some antibiotics and some medicinal plant extracts as many plants are reported to posses antibacterial activities which would be useful in clinical uses but there is no sufficient investigations related to Pseudomonas aeruginosa.

\section{MATERIAL AND METHOD}

\section{1- Collection of samples:}

A total number of 50 samples were collected from farm animals at different localities in Alexandria governorate as the following:-

Table (1): collection of samples:

\begin{tabular}{|c|c|c|c|}
\hline Origin & Animal species & samples & No. of samples \\
\hline Elamira & Calves & Faecal samples & 10 \\
\hline Elmlahat & Sheep and goat & Wounds swabs and abccess & 8 \\
\hline Abbis & Cow & Mastitic milk & 12 \\
\hline Elmaamora & Sheep & Pneumonic lung & 10 \\
\hline Khorshid & Sheep & Nasal swabs & 10 \\
\hline
\end{tabular}


All samples were transferred under aseptic conditions to the laboratory in an icebox; all swabs were kept in tubes with nutrient broth as transported media to avoid dryness

\section{The samples are collected from pathogenic cases as:}

Faecal samples are collected from animals suffering from diarrhea, nasal swabs from animals with respiratory manifestation as nasal discharge and coughing while pneumonic lungs from animals of immediate slaughtering, milk samples are collected from cows of mastitic udder while wounds swabs were obtained from animals have skin affections with suppurative exudates.

\section{2- Bacteriological examination:}

\section{A. Isolation of Pseudomonas aeruqinosa:}

All samples are inoculated into nutrient broth and incubated at $37^{\circ} \mathrm{Cfor} 24$ hours, then all samples were streaked onto nutrient agar and MacConkey's agar media, then incubated aerobically at $37^{\circ} \mathrm{C}$ for 48 hours or at $42^{\circ} \mathrm{C}$ for 24 hours. Suspected colonies were picked up and can be purified by subculturing on nutrient agar or MacConky's agar media, isolated purified colonies were kept onto slope agar then transported to be preserved on semisolid nutrient agar for further identifications.

\section{B. Identification of the isolates:}

Pure isolates were subjected to identification based on the studying of culture character, pigment production, motility, gram staining reaction, detection of musty smell and tests of Catalase, Oxidase, Indole $\overline{\overline{\text { Kafrelsheikh Vet. Med. J. Vol. } 9 \text { No. } 2 \text { (2011) }}}$ 
production, Methyl red, Vogus proskaur, Citrate utilization, Urea hydrolysis and Sugar fermentation Cruickshank et al. (1975) and Koneman et al. (1997).

\section{3- Virulence assay of Pseudomonas aeruginosa:}

Pseudomonas aeruginosa produces a number of exoenzymes which have been implicated as virulence factors in infections caused by this organism and hemolysin is one of these exoenzymes (Jasmine varnes et al.,2001).

\section{Hemolysin Assay:}

Blood agar plates containing 10\% defibrinated sheep blood were used to detect hemolysin activity of single strain, the plates were incubated at $37^{\circ} \mathrm{C}$ for 12 hours (Piyush Bihari Lai et al., 2008).

Positive results showed zones with green or brownish holes (B-Haemolysis).

\section{4- Pathogenicity test:}

Chicken embryos: thirsty, 7 days - old fertile chicken eggs were used, five from them were taken at a random and examined bacteriologically to ensure that they were Pseudomonas aeruginosa free, the remaining twenty five eggs were divided into 2 groups: the first group consisting of twenty eggs and were inoculated via yolk sac route by $0.1 \mathrm{ml}$ of 24 hours broth culture contain $14 \times 10^{7}$ viable cell of Pseudomonas aeruginosa / ml. (Saad et al., 1981). The second groups consisting of five eggs were kept as control. 


\section{5- Sensitivity test:}

The isolates were tested for their sensitivity to some antibiotics discs then the multidrug resistant strains were tested for their sensitivity to some plant extracts.

\section{Antimicrobial activity of antibiotics:}

The antibiograms of the isolated Pseudomonas aeruginosa pathogens were done using the disc diffusion method as recorded by Baeur et al. (1966). The interpretation of inhibition zones were estimated according to limit given by Finegold and Martin (1982) and BioMerieus (1984).

Different antibiotic discs were used such as Nitrofuratoin $(300 \mu \mathrm{g})$,

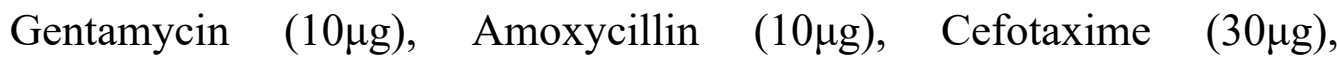
Amoxicillin clavulanic acid $(30 \mu \mathrm{g})$, Ofloxacin $(5 \mu \mathrm{g})$, Polymixine B $(300 \mu \mathrm{g})$, Ciprofloxacin $(5 \mu \mathrm{g})$, Neomycin $(300 \mu \mathrm{g})$, Erythromycin $(15 \mu \mathrm{g})$, Trimethroprime $(25 \mu \mathrm{g})$ and Ampicillin $(10 \mu \mathrm{g})$.

\section{Plant extracts:}

Some plant extracts of Ginger (zingiber afficinale L.), Cinnamon (Cinnamonum burmannil L.)Thyme seed (Thmus vulgaris) and Black seed (Nigella Sativa L.), the plant materials were purchased from local retail markets. $10 \mathrm{gm}$ of the ground material were soaked in $100 \mathrm{ml}$ hot sterile distilled water (and by using water bath at $70^{\circ} \mathrm{C}$ allowed to stand over night) the crude extracts were obtained by centrifuge at $2000 \mathrm{rpm}$ for 15 minutes then filter the supernatant through whatman No.2 filter paper , all extracts were collected in dark bottles and stored at $4^{\circ} \mathrm{Ctill}$ use (Behards. et al. 2009). 


\section{Antimicrobial activity of plant extracts:}

The antibacterial activity of plant extracts was assayed by agar well diffusion method as agar plates were prepared by using Muller Hinton agar; the plates were seeded with $1 \mathrm{ml}$ of tested culture corresponding to $10{ }^{6}$ CFU of cells in nutrient broth. Wells of $3 \mathrm{~mm}$ in diameter were made using a sterile cork borer in solidified agar and $20 \mu \mathrm{l}$ of each plant extracts were added to the wells plates and left for 1 hour at $4^{\circ} \mathrm{C}$ and then incubated at $37^{\circ} \mathrm{C}$ for 24 hours.

Wells without extract were considered as control (Lis - Balchin et al., 1995).

\section{RESULTS}

A total number of 50 samples were investigated. These included 10 faecal swabs from newborn calves with symptoms of diarrhea , 12 milk samples were collected from cows suffering from mastitis , 10 nasal swabs were collected from sheep suffering from respiratory affections , in addition, 10 samples of lung lesions from sheep suffering from pneumonia and finally 8 samples of skin affections were collected from sheep and goat with symptoms of abscess or wounds (Table 1).The bacteriological examination of these samples revealed the isolation of 10 isolates of Pseudomonas aeruginosa. From which one isolate (10\%) was positive from 10 examined rectal swab samples collected from calves with symptoms of diarrhoea, one isolate (8.3\%) was positive from 12 mastitic milk samples collected from cow, 2 isolates (20\%) were positive from 10 examined nasal swabs samples collected from sheep, 4 isolates (40\%) were positive from 10 examined lung with lesions of pneumonia in sheep and 2 isolates (25\%) were positive from 8 samples collected from wound and abscess of sheep and goat (Table 2). 
Ola. A. M. Basha

Table (2): Incidence of Pseudomonas aeruginosa among investigated samples

\begin{tabular}{|c||c||c||c||c||}
\hline Species & samples & No. of samples & No. of positive isolates & \% of +ve isolates \\
\hline \hline Calves & Faecal samples & 10 & 1 & 10 \\
\hline Cows & Milk & 12 & 1 & 8.3 \\
\hline Sheep & Nasal swab & 10 & 2 & 20 \\
\hline Sheep & Lung lesion & 10 & 4 & 40 \\
\hline Sheep and goat & Wound or abscess & 8 & 2 & 25 \\
\hline \hline Total & & $\mathbf{5 0}$ & $\mathbf{1 0}$ & $\mathbf{2 0}$ \\
\hline
\end{tabular}

Table (3): Morphological and biochemical characteristics of Pseudomonas aeruginosa.

\begin{tabular}{|c|c|}
\hline Test & Result \\
\hline Gram stain & - ve \\
\hline Motility & +ve \\
\hline Indol & - ve \\
\hline Nitrate & +ve \\
\hline H2S production & - ve \\
\hline Oxidase & +ve \\
\hline Catalase & +ve \\
\hline Citrate & +ve \\
\hline Methyl red & - ve \\
\hline Vogus proskaur & - ve \\
\hline Urease & +ve \\
\hline \multicolumn{2}{|l|}{ Sugar fermentation } \\
\hline Glucose & +ve \\
\hline Lactose & - ve \\
\hline Sucrose & - ve \\
\hline Mannitol & - ve \\
\hline Maltose & - ve \\
\hline Dulcitol & - ve \\
\hline
\end{tabular}

Kafrelsheikh Vet. Med. J. Vol. 9 No. 2 (2011) 
The organisms were gram negative, motile, rod shaped, the growth having a metallic sheen and characteristic aromatic grape like odour with greenish blue fluorescence. The morphological and biochemical characteristics of Pseudomonas aeruginosa are illustrated in table (3).

Regarding to virulence activity of Pseudomonas aeruginosa isolates it was found that 8 isolates out of 10 isolates recovered at this study, produced exoenzymes and produced B- Hemolysis on 10\% defibrinated sheep blood agar (Table 4).

Table (4): Hemolysis assay of Pseudomonas aeruginosa of farm animals.

\begin{tabular}{|c||c||c|}
\hline Type of Hemolysis & No. of isolates & \% \\
\hline \hline B- Hemolysis & 8 & 80 \\
\hline No Hemolysis & 2 & 20 \\
\hline \hline Total & $\mathbf{1 0}$ & $\mathbf{1 0 0}$ \\
\hline
\end{tabular}

Result of Pathogenicity test revealed that, chicken embryos inoculated with Pseudomonas aeruginosa isolates showing 100\% mortality to the embryos between day 2-4 post inoculation with formation of caseated material. Reisolation of Pseudomonas aeruginosa from inoculated chicken embryos was succeeded.

The results of drug sensitivity were summarized in table (5). The results revealed that Pseudomonas aeruginosa was sensitive to Gentamycin ,Ofloxacin and Ciprofloxacin, had high resistance (100\%) to Amoxicillin, Cefotaxim, Erythromycin Ampicillin and Trimethoprim.

Regarding to the results of antimicrobial activities for some plant extracts against multiple drug resistant Pseudomonas aeruginosa are illustrated in table (6). The test explained that aqueous extract of Ginger, Thyme, Cinnamon and Black seed did not inhibit any of the tested organisms. 
Table (5): Invitro-sensitivity of Pseudomonas aeruginosa to different antibiotics by disk diffusion agar.

\begin{tabular}{|c||c|}
\hline Antibiotic disc & Reaction \\
\hline \hline Nitrofuratoin $300 \mu \mathrm{g}$ & - \\
\hline Gentamycin $10 \mu \mathrm{g}$ & +++ \\
\hline Amoxicillin $10 \mu \mathrm{g}$ & - \\
\hline Cefotaxime $30 \mu \mathrm{g}$ & - \\
\hline Amoxicillin clavulanic acid $30 \mu \mathrm{g}$ & - \\
\hline Ofloxacin $5 \mu \mathrm{g}$ & +++ \\
\hline Polymxin B $300 \mu \mathrm{g}$ & + \\
\hline CiproFloxacin $5 \mu \mathrm{g}$ & ++++ \\
\hline Neomycin $30 \mu \mathrm{g}$ & + \\
\hline Erythromycin $15 \mu \mathrm{g}$ & - \\
\hline Trimethoprim $25 \mu \mathrm{g}$ & - \\
\hline Ampicillin $10 \mu \mathrm{g}$ & - \\
\hline
\end{tabular}

Table (6): Antibacterial activities of plant extracts against multidrug resistant strains of pseudomonas aeruginosa grow on Muller Hinton agar by agar well diffusion.

\begin{tabular}{|c|c|}
\hline Tested plant extracts & Reaction \\
\hline \hline Ginger & - \\
\hline Thyme & - \\
\hline Cinnamon & - \\
\hline Black seed & - \\
\hline
\end{tabular}

\section{DISCUSSION}

Pseudomonas aeruginosa is an opportunistic pathogen that may cause broad spectrum of infections in urinary, respiratory, gastrointestinal tract, eyes and other sites of the body (Hancock and Speert, 2000 and Rahul Mittal, 2006). In the present research, Pseudomonas aeruginosa could be isolated in percentage of $20 \%$ from samples collected from farm diseased animals. There are 10 rectal swabs collected from calves suffering from diarrhoea and revealed one isolate Kafrelsheikh Vet. Med. J. Vol. 9 No. 2 (2011) 
positive (10\%), and one isolate (8.3\%) out of 12 milk samples from mastitic cows, and 2 (20\%) positive out of 10 nasal discharge of sheep with respiratory affections, and 4 (40\%) positive out of 10 samples of lung lesions collected from slaughtered sheep with pneumonia and finally 2 (25\%) positive isolates out of samples collected from infected wound and abscess of sheep and goats.

These results having total of 10 isolates out of 50 examined samples from different animal species and represented as $20 \%$. These results were higher than those recorded by El-Amrousi et al.,(1972) who reported 1.5\% Pseudomonas aeruginosa from diarrhoeic calves, Talaat (1993) who reported $15.8 \%$ from buffaloes ,while Gamal (1995) could isolate Pseudomonas aeruginosa at $11.8 \%$ from large animals, Walaa (2004) isolated the organism at $10.28 \%$ from different animals species and Arsalan et al.,(2009) recorded that Pseudomonas aeruginosa could be isolated at 5.5\% from examined infected sheep. On the other hand, these results were lower than that reported by Voss (1982) who recovered 26\% positive out of 319 calves had digestive disorders.

Table (3) illustrated the morphological and biochemical tests characterized for Pseudomonas aeruginosa isolates which were inagreement with (Robert, et al., 2003).

The results of virulence assay of Pseudomonas aeruginosa table (4) indicated that eight isolates out of 10 isolates gave B-hemolysis (80\%) while 2 isolates (20\%) were give no hemolysis. Similar results were reported by Gehan et al. (2011) who recorded 65 out of 69 Pseudomonas aeruginosa strains gave positive hemolysis activity on blood agar. Moreover, Miyazaki et al. (1995) reported that Pseudomonas aeruginosa produce extracellular enzyme cytotoxin and haemolysin. 
In this present study, the results of experimental infection of isolated organism to chicken embryos revealed $100 \%$ mortality to embryos, this result is inagreement with that reported by saad et al. (1978), and therefore, Pseudomonas aeruginosa is considered to be a true pathogen when it is reisolated from sterile site and had been classified as a significant pathogen (Shiferaw, G., et al., 2006).

In vitro sensitivity testing of the isolates to antimicrobial agents revealed that the isolates were highly sensitive to Ofloxacin, Ciprofloxacin and Gentamycin as showen in table (5). These results are in agreement with that reported by EI- shorbagy et al.(2001), EIShouny and Magaam (2009) and Gehan et al. (2011), while all isolates were resistant to great different types of chemotherapeutics used in the present study The great variations in the results of antibiotic sensitivity of Pseudomonas aeruginosa isolates can be attributed to the physiochemical properties of the cell wall rather than the antibiotic inhibiting enzymes (Koncicki and Szubstraska,1988).

Concerning the sensitivity of Pseudomonas aeruginosa to natural and efficient substances which could inhibit growth of bacteria which can resist antibiotics were reported by Hammr et al. (1999), Dorman and Dean, (2000); Lee et al., (2004). In the present study, results mentioned in the table (6) revealed that aqueous extracts of Ginger, Thyme, Cinnamon and black seed could not inhibit any of tested isolates. These results were in agreement with Gehan et al.,(2011) which recorded that Thyme and Ginger extracts have no antibacterial activity at any tested concentration while El-Shouny and Magaam (2009) reported that Ginger extracted was the most effective agent followed by Cinnamon and Thyme. 
In a conclusion, this study reflects the defect of the extensive use and misuse of antibiotics which have favoured the resistant of the microorganisms. In the treatment, especially when caused by pathogens that often drug resistant, sensitivity testing must be used to select effective antimicrobial drugs. In addition, vitro studies would be rewarding to test more pathogenic bacteria inorder to recommend further use of plant extracts in the possible treatment of multi-drug resistant infectious microorganisms.

\section{REFERENES}

- AL.Farwachi M.I. and M.M. AL- Hassan (2008): Clinical and Microbiological study of otitis externa in sheep. Iraqi Journal of vet.scie.vol.22 No.1 $43-48$.

- Arici,M.;O.Sagdic and U.Gecgal (2005): Antibacterial effect of Turkish blackcumin (Nigella Satival.) oils Grasas Y Aceites, 56 (4): 259-262.

- Arslan, S.H.;Al-gammaly,M.H. and. Khaleel G.s. (2009): Diagnosis of causes of suppurative arthritis in sheep in Mosul, Iraq. Iraqi Journal of vet. Scien.,vol.23,No.2, 115 - 119.

- Baeur, A. W.; Kirby, W. M. M.; Sherris, K. C. Twrck, K. C. and Turck, .M (1966): Antibiotic susceptibility testing by a standardized single disk method. American J.Clinical pathology,Vol.45 No.1: 493-496.

- Behard,S.; Youssef, M.Y; Goh,K.L. and Baba,A.S.(2009): Manipulation of probiotics fermentation of yogurt by cinnamon and Licorica: effects on yogurt formation and Inhibition of Helicobacter pylori growth in vitro. World academy of science, Engineering and Technology 60. 
- Bio-Merieus (1984): Laboratory reagent and products.Bacteriology Ma.Cly.l Etoile69260.Charbonmiees les-Bains. France.

- Cornialis,P., (2008): Pseudomonas; Genomics and molecular Biology. 1st Edn.Caister Academic press.

- Cruickshank, R.; Duiguid, J.P.; Marmion, B.P and Swan, R.H.A. (1975): Medical microbiology $12^{\text {th }}$ E.D.vol. II, Churchill Livingstone, Edinburgh, London and Newyork.

- Dorman, H. J. D. and S. G. Dean, (2000): Antimicrobial agents from plants: Antibacterial activity of plant volatile oils. J. Applied Microbiol., 88:308 - 316.

- El-Amrousi, S.; Nafei, E. K.; El-Rehawi, M.; and Abdel-Motilib (1972): Studies on enteritis in buffalocalves in Assuit. J. Egypt. vet. Med. Ass., 31 (34): 219 - 225.

- El-Shorbagy, M. A.; Mosaad, A. A.; Boushra, M. H. and, Mervat, M. A. (2001): Studies on Pseudomonas aeruginosa infection in quails J. Egypt. vet. Med. Ass., 61(1):205-221.

- EL-Shouny W. A. and Magaam S.(2009): Ssnsitivity of multidrug resistant Pseudomonas aeruginosa isolated from surgical woundinfections to essential oils and plant eotracts . World J. of Med. Scien. $4(2): 104-111$.

- Finegold, S. M. and Martin, W. T. (1982): Diagnostic Microbiology 6th E.d.,TH Mosby Company, USA.

- Gamal Ragab, H.E.N.(1995): A contribution on the characters of Pseudomonas and Aeromonas Ph.D., Microbiology Thesis. Fac. vet. Med. Alex. Univ., Egypt. 
- Gehan M.Kamel, N.A. Ezzeldeen, Mostafa yousef El- Mishad and Reham Farouk Ezzat (2011): Susceptibility pattern of Pseudomonas aeruginosa Against Antimicrobial Agents and some plant extracts with focus on its prevalence in different sources. Global Vetrinaria 6 (1):61-72.

- Hammer, A. K., C. F. Carson and T. V. Riley (1999): Antimicrobial activity of essential oils and other plant extracts. J. Appl. Microbiol., 86:985-990

- Hancock, R. E. and speert, D. P. (2000): Antibiotic resistance in Pseudomonas aeruginosa mechanisms and impact on treatment.Drug Resist. Update.,3(4):247-255

- Howell, D.(1972): Survey on mastitis caused by environmental bacteria. Vet.Rec.,90-554.

- Jaime H.Samour (2000): Pseudomonas aeruginosa stomatitis as a sequal to trichomoniasis in Captive Saker Falcons.Journal of Avian medicine and surgey 14 (2) 113 - 117.

- Jasmine varnes, Ivana Brkic and Mira Horonitz (2001): Differences in the antigenic structure and production of hemolysin of Pseudomonas aeruginosa strains isolated from a variety of isolation sites,Acta clinica croatica 40(2): 85-91.

- Kolev,v.; Veneve,S.;Markaran,M.;and davavo I.(1983): Intrauterine bacterial and mycotic infection in cows.Vet. Med. Nauki.20:33-40.

- Koncicki, A. and Szubstarska, A.(1988): Role of Pseudomonas aeruginosa in poultry diseases. Weterynaryjna.,44(80): 474-477. 
- Koneman, W. E.; Aven, D. S.; Kanada, M.W.; Scheckanberger, C.P. and winn, C. W. (1997): Colour Atlas and textbook of diagnostic microbiology. Lippincoott. Newyork, USA.

- Kovacs, K.; paterson D.L. and Yu, v. L.(1998): Antimicrobiol therapy of Pseudomonas aerginosa: Therapeutic issues; resistance; pneumonia; endocasditis and infections of G I tract, bone and Joint. And urinary tract. Infect.Med.,15(6): 385-394.

- Lee, K. W., H. Everts and A.C. Beynen, (2004): Essential oils in Boiler nutrition. Int.J.poult. Sci.3:738-752.

- Lis - Balchin, M., S. L. Hart, S.G. Deans and E.Eaglesham (1995): potential agrochemical and mechanical usage of essential oils of pelargonium sp.J.Herbs spices and medicinal plants 3:11 - 22 .

- Miya zaki shuichi, Tetsuya Matsumoto, kazuhiro Tateda, Akira ohno and keizo yama guchi (1995): Role of exotoxin A in inducing severe Pseudomonas aeruginosa infections in mice J. Med. Microbiol. vol. 43. $169-175$.

- Piyush Biharilal, Naresh Kumar, Tasleem Arif, T.K.Mandal, K.Akhilesh verma, G.L.Sharma and Rajesh Dabur (2008): In vitro antibacterial activity of a novel isoquinoline derivative and its post antibacterial effects on Pseudomonas aeruginosa. African J.of Micro. Research vol.(2) 126 - 130.

- Quinn, P. J.; Carter, M.E., Markey, B. K; Donney, w. J. and Leonard, F. c. (2002): Clinical Veterinary microbiology. Wolf, London, Newyork. P.124 - 127. 
- Rahul Mittal (2006): phenotypic characters of urinary isolates of Pseudomonas aeruginosa and their association with mous renal colonization. Indian J.Med.Res.123 January 2006 (67 - 72).

- Robert, S., R. L. Anders, F. Niels and Frabk, (2003): Evaluation of different disk diffustion / media for detection of methicillin resistance in Staphylococcus aureus and coagulase - negative staphylococci APMIS,111: 905 - 914.

- Saad ,E. E.; Youssef, Y. I. and Awaad, M.H. (1981): Effect of Pseudomonas aerginosa on chicken embryos. vet. Med. J. Caro University., (29): 129 - 133.

- Shiferaw, G.; Tariku, S.; Ayelet, G.; and Abebe Z. (2006): Contagious caprine pleuropneumonia and Mannheimia haemolytica associated acute respiratory disease of goats and sheep in Afar region, Ethiopia. Ref.Sci.tech.Off.int.Epiz.25(3)1153-1163.

- Talaat, w.B. (1993): Studies on Pseudomonas species isolated from animals. Zagazig vet.J.21 (1): 37.

- Todar's (2008) : Online text book of Bacteriology (Internet).

- Voss, L. M. (1982): Clinical pathology and bacteriological diagnosis for cattle submitted M.M.examination and tests on their resistance to diseases Inagural. Dissertation, Tierarztliche Hechshule Hannover vol.87.

- Walaa I.A.Omar (2004): Antibiotics resistance of Pseudomonas species isolated from Fish and Farm Animals. M.V.Sc., Thesis. Fac. Vet. Med. Alex. Univ. 
بعض الدراسات عن تواجد ميكروبات السودوموناس المعزولة من حيوانات المزرعة اشتملت الدراسة على فحص عدد 50 عينة مجمعة من حيوانات المزرعة التى تعانى من اعراض مرضية والمنتشرة فى مناطق مختلفة بمحافظة الإسكندرية وذلك لتحديد مدى تواجد ميكروبات السودوموناس بها. وكانت نتيجة الفحص البكتريولوجى عزل بكتريا السودوموناس ارجينوزامن العينات بنسبة 20\% حيث تم العزل من 10 عينات لعجول تعانى من الإسهال, 12 عينة لبن من ابقار تعانى

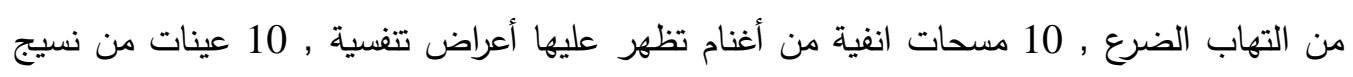
رئوى لأغنام ذبحت اضطراريا و8 عينات من جروح الأغنام و الماعز فكانت نسبة العزل 10, 8,3 , 20, 40, 25 \% بالترتيب.

وقد تم دراسة تأثير ضراوة العترات المعزولة على أطباق آجار الدم حيث استطاع 8 عترات من 10 عترات معزولة من ميكروب السودوموناس ارجينوزا أن يحدث تحلل بيتا على الأطباق. وتم إجراء

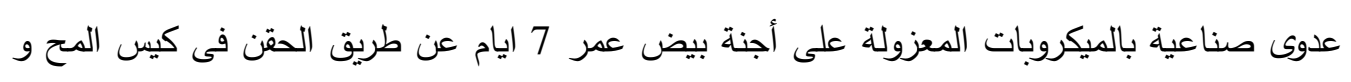
الذي أدى إلى نفوق لجميع الأجنة.

وبإجراء اختبارات الحساسية لميكروبات السودوموناس ارجينوزا المعزولة وجد ان أقراص الاوفلوكساسين, السييروفلوكساسين والجنتاميسين هم الأكثر تأثيرا بينما اظهر مقاومة لكل من النيتروفيوراتوين, الاموكسيسللين, السيفوتاكسيم, الارثرومايسين و التزايميثوبريم ولألك تم إجراء اختبارات الحساسية باستخدام بعض مستخلصات النباتات التى أثتتت مقاومة لبعض الأنواع الأخرى من البكتريا

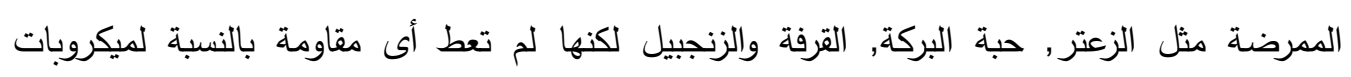

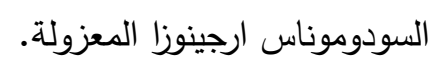

